\title{
PENGARUH PEMBIAYAAN MUDHARABAH, MUSYARAKAH, DAN MURABAHAH TERHADAP RETURN ON ASSET MELALUI NON PERFORMING FINANCING SEBAGAI VARIABEL INTERVENING (PADA BANK UMUM SYARIAH YANG TERDAFTAR DIOTORITAS JASA KEUANGAN)
}

\author{
Anisya Dwi Fazriani ${ }^{1}$, Rimi Gusliana Mais ${ }^{2}$ \\ Program Studi Akuntansi \\ Sekolah Tinggi Ilmu Ekonomi Indonesia Jakarta Indonesia \\ anisyadwifazriani@gmail.com, rimigusliana@gmail.com
}

\begin{abstract}
Abstrak - Penelitian ini bertujuan untuk mengetahui pengaruh pembiayaan mudharabah, musyarakah, dan murabahah terhadap Return on Assets melalui Non Performing Financing sebagai variable intervening pada Bank Umum Syariah yang terdaftar di OJK Periode 2013-2018. Penelitian ini menggunakan sampel bank umum syariah yang terdaftar di OJK sebanyak 11 bank dengan periode 2013-2018. Penelitian ini menggunakan data sekunder dengan teknik pengumpulan data menggunakan Purposive Sampling dan dianalisis menggunakan Software Eviews versi 10. Berdasarkan hasil penelitian ditemukan bahwa Pembiayaan mudharabah, musyarakah dan murabahah berpengaruh negatif terhadap ROA. Pembiayaan mudharabah dan murabahah berpengaruh negatif terhadap NPF. Sementara pembiayaan musyarakah berpengaruh positif terhadap NPF. NPF tidak berpengaruh terhadap ROA. Pembiayaan mudharabah berpengaruh negatif terhadap ROA melalui NPF sebagai variabel intervening. Pembiayaan musyarakah dan murabahah berpengaruh positif terhadap ROA melalui NPF sebagai variabel intervening.
\end{abstract}

Kata Kunci : Mudharabah, Musyarakah, Murabahah, NPF, ROA 


\section{PENDAHULUAN}

Seiring dengan pesatnya pertumbuhan bank syariah di Indonesia, kepercayaan masyarakat terhadap perbankan syariah pun meningkat. Kondisi seperti ini dimanfaatkan oleh bank syariah dengan terus memberikan pengetahuan serta pemahaman kepada masyarakat mengenai perbankan syariah dengan harapan dapat meningkatkan pangsa pasarnya. Peran masyarakat dalam kelangsungan usaha bank syariah sangatlah penting karena pada dasarnya bank berdiri atas dasar kepercayaan. Oleh sebab itu kepercayaan masyarakat terhadap bank syariah harus tetap di jaga dan di tingkatkan oleh bank syariah. Simpati dan kepercayaan masyarakat tersebut terhadap suatu bank tidak terlepas dari kondisi keuangan bank, termasuk kesehatan bank tersebut. Menurut Taswan (2010:537), tingkat kesehatan bank merupakan kemampuan suatu bank untuk melakukan kegiatan operarional perbankan secara normal dan mampu memenuhi semua kewajibannya dengan baik dengan cara-cara yang sesuai dengan peraturan perbankan yang berlaku.

Machmud dan Rukmana (2010) menjelaskan bahwa bank syariah menawarkan beberapa variasi produk yang dapat dipilih nasabah dengan prinsip-prinsip saling menguntungkan. Pelarangan terhadap riba dan penerapan prinsip-prinsip keadilan harus menjadi pegangan dalam melaksanakan kegiatan usaha bank. Untuk menjalankan kegiatannya yang berprinsip syariah, perbankan syariah menawarkan produk-produk yang terbebas dari unsur riba. Skema produk perbankan syariah secara alami merujuk kepada dua kategori kegiatan ekonomi yaitu produksi dan distribusi. Kategori pertama difasilitasi melalui skema profit sharing (mudharabah) dan partnership (musyarakah), sedangkan kegiatan distribusi manfaat hasil-hasil produk dilakukan melaui skema jual beli (murabahah dan sewa menyewa atau ijarah).

Berdasarkan publikasi statistika perbankan syariah yang dilakukan oleh Otoritas Jasa Keuangan menunjukan bahwa akad yang paling berkembang pesat dan mengalami peningkatan setiap tahunnya dalam pembiayaan di bank syariah adalah akad mudharabah, musyarakah, dan murabahah. Hal ini membuktikan bahwa minat masyarakat atas pembiayaan cukup besar. Berikut ini adalah total pembiayaan berdasarkan akad mudharabah, musyarakah, dan murabahah: 


\section{Tabel 1.Pembiayaan Perbankan Syariah}

\begin{tabular}{|c|c|c|c|c|c|c|}
\hline Akad & $\mathbf{2 0 1 3}$ & $\mathbf{2 0 1 4}$ & $\mathbf{2 0 1 5}$ & $\mathbf{2 0 1 6}$ & $\mathbf{2 0 1 7}$ & $\mathbf{2 0 1 8}$ \\
\hline Mudharabah & 13,625 & 14,354 & 14,820 & 15,292 & 17,090 & 15,970 \\
\hline Musyarakah & 39,874 & 49,336 & 60,713 & 78,421 & 101,561 & 112,349 \\
\hline Murabahah & 110,565 & 117,371 & 122,111 & 139,536 & 150,276 & 152,022 \\
\hline Total & $\mathbf{1 6 4 , 0 6 4}$ & $\mathbf{1 8 1 , 0 6 1}$ & $\mathbf{1 9 7 , 6 4 4}$ & $\mathbf{2 3 3 , 2 4 9}$ & $\mathbf{2 6 8 , 9 2 7}$ & $\mathbf{2 8 0 , 3 4 1}$ \\
\hline
\end{tabular}

Sumber: Statistik Perbankan Syariah, Otoritas Jasa Keuangan (OJK)

Setiap produk yang dikeluarkan oleh bank memiliki tujuan untuk memberikan keuntungan atau meningkatkan profitabilitas bagi pihak bank. Menurut Hery (2015:143), rasio profitabilitas merupakan rasio yang menggambarkan perusahaan dalam menghasilkan laba.

Laba atau keuntungan ini dapat dilihat dari tingkat profitabilitas yang dapat diukur menggunakan rasio keuangan. Salah satu rasio keuangan yang digunakan adalah rasio Return on Assets (ROA). Rasio ROA merupakan rasio untuk mengukur kemampuan perusahaan dalam menghasilkan laba dengan menggunakan total aset (kekayaan) yang dipunyai perusahaan setelah disesuaikan dengan biaya-biaya untuk mendanai aset tersebut. Kemudian menurut Hery (2015:144), return on assets merupakan rasio yang menunjukan hasil (return) atas penggunaan asset perusahaan dalam menciptakan laba bersih. Dengan kata lain rasio ini digunakan mengukur seberapa jumlah laba bersih yang akan dihasilkan dari setiap rupiah dana yang tertanam dalam total asset.

Namun kenaikan pembiayaan dengan akad mudharabah, musyarakah dan murabahah yang terjadi pada tahun 2013-2018 tersebut tidak diikuti dengan meningkatnya tingkat profitabilitas dari Bank Umum Syariah dan Unit Usaha Syariah, hal ini dapat dilihat dari rasio keuangan ROA pada tahun 2014 dan 2015 yang mengalami penurunan, pada tahun 2014 ROA menjadi 1,19\% yang sebelumnya pada tahun 2013 sebesar 2,00\%. Kemudian pada tahun 2015 ROA mengalami penurunan kembali menjadi $1.15 \%$. Hal ini dapat dilihat dari tabel berikut ini:

Tabel 2.Rasio Return on Asset

\begin{tabular}{|c|c|c|c|c|c|c|}
\hline Rasio & $\mathbf{2 0 1 3}$ & $\mathbf{2 0 1 4}$ & $\mathbf{2 0 1 5}$ & $\mathbf{2 0 1 6}$ & $\mathbf{2 0 1 7}$ & $\mathbf{2 0 1 8}$ \\
\hline Return on Assets (ROA) & $2.00 \%$ & $1.19 \%$ & $1.15 \%$ & $1.20 \%$ & $1.55 \%$ & $1.76 \%$ \\
\hline
\end{tabular}

Sumber:Statistik Perbankan Syariah, Otoritas Jasa Keuangan (OJK)

Hal ini tidak sejalan dengan Ismail (2016:87) yang mengatakan bahwa pembiayaan akan berpengaruh pada peningkatan profitabilitas bank. Hal ini dapat 
tercermin pada perolehan laba. Dengan adanya peningkatan laba usaha bank akan menyebabkan kenaikan tingkat profitabilitas bank. Kemudian dalam penelitian yang dilakukan oleh Felani (2017) yang berjudul "Pengaruh Pendapatan Mudharabah, Musyarakah dan Murabahah terhadap Profitabilitas (ROA)" bahwa pembiayaan mudharabah secara parsial berpengaruh negatif terhadap ROA. Pembiayaan musyarakah mempunyai pengaruh yang positif terhadap ROA. Dan pembiayaan murabahah mempunyai pengaruh yang negatif terhadap ROA. Kemudian menurut Chalifah (2015) dalam penelitian yang berjudul "Pengaruh Pendapatan Mudharabah dan Musyarakah terhadap Profitabilitas (ROA)" menyatakan bahwa Pendapatan Musyarakah memiliki efek negatif yang signifikan terhadap ROA. Namun menurut Romdhoni (2018) dalam penelitian "Pengaruh pembiayaan mudharabah, musyarakah dan ijarah terhadap profitabilitas" menyatakan bahwa pembiayaan mudharabah tidak berpengaruh terhadap profitabilitas (ROA) Sedangkan menurut penelitian Zaim (2014) yang berjudul "Pengaruh Pembiayaan Murabahah terhadap Laba Melalui Variabel Intervening Pembiayaan Bermasalah Bank Umum Syariah" bahwa pembiayaan murabahah berpengaruh positif terhadap laba. Hasil penelitian yang telah dilakukan sebelumnya tesebut menunjukan hasil yang beragam (research gap).

Adanya pembiayaan yang diberikan oleh bank kepada nasabah tidak terlepas dari adanya risiko kredit. Risiko kredit dapat ditunjukan oleh tingkat Non Performing Financing (NPF). Berikut ini adalah Presentase Non Performing Financing (NPF) BUSUUS Periode 2014-2018:

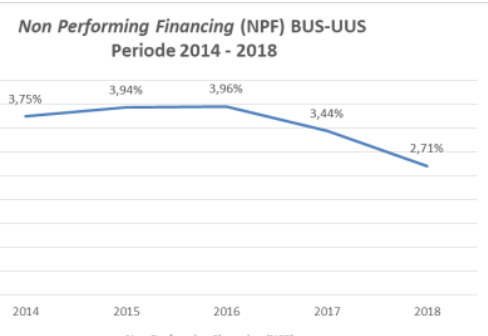

Gambar 1.Presentase Non Performing Financing (NPF)

Sumber:Statistik Perbankan Syariah, Otoritas Jasa Keuangan (OJK)

Risiko kredit yang ditunjukan oleh tingkat Non Performing Financing (NPF) cenderung meningkat dari tahun 2014 sampai dengan tahun 2016 meskipun masih dibawah 5\%. Pada tahun 2016 NPF Gross mencapai 3,96\%, nilai ini lebih besar dibandingkan dengan tahun lalu yang sebesar 3,94\%. 
Bank syariah dalam menyalurkan dananya kepada masyarakat tidak akan terlepas dari risiko pembiayaan dalam penyaluran dana nya tersebut. Risiko dalam pembiayaan biasa disebut dengan pembiayaan bermasalah atau Non Performing Financing (NPF). Penelitian mengenai NPF yang dilakukan oleh Adyani dan Sampurno (2012) menunjukan bahwa NPF berpengaruh negatif terhadap profitabilitas (ROA). Semakin besar NPF maka kinerja bank semakin buruk karena ROA nya rendah. Namun penelitian ini bertentangan dengan penelitian yang dilakukan oleh Zaim (2014) yang menunjukan bahwa NPF tidak bepengaruh terhadap profitabilitas. Hasil penelitian yang telah dilakukan sebelumnya tesebut menunjukan hasil yang beragam (research gap).

Berdasarkan uraian latar belakang di atas, maka peneliti tertarik untuk melakukan penelitian dengan judul "Pengaruh Pembiayaan Mudharabah, Musyarakah dan Murabahah terhadap Profitabilitas (ROA) dengan Non Performing Financing (NPF) Sebagai Variabel Intervening Pada Bank Umum Syariah (BUS) yang terdaftar dalam Otoritas Jasa Keuangan di Indonesia”

\section{KAJIAN PUSTAKA, KERANGKA PEMIKIRAN DAN HIPOTESIS}

Menurut Triyuwono (2015:355) mengemukakan akuntansi syariah tidak saja sebagai bentuk akuntabilitas (accountability) manajemen terhadap pemilik perusahaan (stockholders), tetapi juga sebagai akuntabilitas kepada stakeholders dan Tuhan. Enterprise theory mengandung nilai keadilan, kebenaran, kejujuran, amanah, dan pertanggung jawaban, bentuk pertanggungjawaban utamanya kepada Allah SWT.

Syariah Enterprise Theory menurut Slamet dalam Triyuwono, (2015:356) menjelaskan bahwa aksioma terpenting yang harus mendasari dalam setiap penetapan konsepnya adalah Allah sebagai Pencipta dan Pemilik Tunggal dari seluruh sumber daya yang ada di dunia ini. Sedangkan sumber daya yang dimiliki oleh para stakeholders pada prinsipnya adalah amanah dari Allah SWT yang di dalamnya melekat tanggung jawab untuk digunakan dengan cara dan tujuan yang ditetapkan oleh Sang Pemberi Amanah.

Menurut Triyuwono (2015:357), Syariah Enterprise Theory memiliki pandangan dalam distribusi kekayaan (wealth) atau nilai tambah (value added) tidak hanya berlaku pada partisipan yang terkait langsung atau partisipan yang memberikan kontribusi kepada operasi perusahaan (pemegang saham, kreditur, karyawan, pemerintah), tetapi juga terhadap pihak lain yang tidak terkait secara langsung terhadap operasi perusahaan. 
Oleh karena itu, syariah enterprise theory akan membawa kemaslahatan bagi stockholders, stakeholders, masyarakat dan lingkungan alam tanpa meninggalkan kewajiban penting menunaikan zakat sebagai manifestasi ibadah kepada Allah.

Implikasi Teori Syariah Enterprise pada penelitian ini dimana bank umum syariah harus berlandaskan syariah enterprise theory dalam melaksanakan tugasnya, karena bank umum syariah tidak hanya bertanggung jawab kepada pemilik melainkan kepada stakeholders dan Allah SWT. Penerapan prinsip syariah enterprise theory pada bank umum syariah akan membuat kinerja bank lebih sehat, dikarenakan manajemen akan mematuhi prinsip-prinsip yang telah ditetapkan. Semakin tinggi kepatuhan syariah dan penerapan Islamic corporate government dalam menerapkan prinsip tersebut memungkinkan bank untuk mendapatkan kategori bank sehat. Bank umum syariah juga akan lebih berhati-hati dalam melaksanakan tugasnya sehingga dapat menimimalisir tindak kecurangan yang mungkin dilakukan. Penerapan prinsip syariah enterprise theory pada bank umum syariah harus memberikan informasi yang akurat dan transparan, sehingga pemilik modal yakin akan kebenaran informasi laporan keuangan yang di terbitkan oleh pihak bank umum syariah.

\section{Profitabilitas}

Menurut Kasmir (2012:327) profitabilitas merupakan kemampuan yang dimiliki oleh suatu perusahaan dalam menghasilkan laba. Sebutan lain untuk profitabilitas adalah rasio rentabilitas. Rasio ini digunakan untuk mengukur tingkat efisiensi usaha dan profitabilitas yang dicapai oleh bank yang bersangkutan. Sedangkan menurut Hery (2016:192) Profitabilitas merupakan rasio yang digunakan untuk mengukur kemampuan perusahaan dalam menghasilkan laba dari aktivitas normal bisnisnya.

Menurut Tandelilin (2010:372), untuk melakukan analisis perusahaan, disamping dilakukan dengan melihat laporan keuangan perusahaan, juga dilakukan dengan menggunakan analisis rasio keuangan. Dari sudut pandang investor, salah satu indikator penting untuk menilai prospek perusahaan di masa datang adalah dengan melihat sejauh mana pertumbuhan profitailitas perusahaan. Indikator ini sangat penting dilakukan untuk mengetahui sejauh mana investasi yang dilakukan investor disuatu perusahaan mampu memberikan return yang sesuai dengan tingkat yang disyaratkan investor.

Dalam penelitian ini perhitungan profitabilitas menggunakan sebuah alat pengukuran yang disebut ROA (Return on Assets). Menurut Hanafi (2016:157) ROA 
mengukur kemampuan perusahaan menghasilkan laba dengan menggunakan total aset (kekayaan) yang dipunyai perusahaan setelah disesuaikan dengan biaya-biaya untuk mendanai aset tersebut. Profitabilitas merupakan tujuan utama dari suatu perusahaan, di samping itu profitabilitas juga dapat digunakan untuk mengukur kinerja suatu perusahaan. Menurut Prasetyo (2015) semakin tinggi tingkat profitabilitas dan terusmenerus memperoleh profitabilitas, maka semakin baik kinerja perbankan atau perusahaan dan kelangsungan hidup perbankan atau perusahaan tersebut akan terjamin.

\section{Non Performing Financing (NPF)}

Menurut Ikatan Bankir Indonesia (2015:309), Non Performing Financing (NPF) adalah kredit bermasalah yang terdiri dari kredit yang berklasifikasi Kredit Kurang Lancar, Kredit Diragukan dan Kredit Macet. Termin Non Performing Loan (NPL) digunakan bagi bank umum, sedangkan Non Performing Financing (NPF) digunakan untuk bank syariah.

Menurut Pernyataan Standar Akuntansi Keuangan PSAK No. 31 Revisi 2000 Paragraf 24, disebutkan bahwa kredit Non Performing pada umumnya merupakan kredit yang pembayaran angsuran pokok dan/atau bunganya telah lewat sembilan puluh hari atau lebih setelah jatuh tempo, atau kredit yang pembayarannya secara tepat waktu sangat diragukan. Kredit Non Performing terdiri atas kredit yang digolongkan sebagai kredit kurang lancar, diragukan, dan macet.

Non Perorming Financing (NPF) atau pembiayaan bermasalah merupakan salah satu indikator untuk menilai kinerja bank, menurut Hadiyati (2013). Menurut Mahmoeddin (2010:3), Non Performing Financing pada dasarnya disebabkan oleh faktor intern dan ekstern. Kedua faktor tersebut tidak dapat dihindari mengingat adanya kepentingan yang saling berkaitan sehingga mempengaruhi kegiatan usaha bank.

Non Performing Financing (NPF) semakin tinggi maka profitabilitas akan semakin rendah dan sebaliknya, jika Non Performing Financing (NPF) semakin rendah maka profitabilitas akan semakin tinggi. Seperti yang diungkapkan oleh Abdullah (2010:205), jika kredit bermasalah sangat besar dan cadangan yang dibentuk juga besar berakibat modal bank kemungkinan menjadi negatif sehingga laba yang diperoleh menjadi terganggu.

Pembiayaan bermasalah dalam jumlah besar akan menurunkan tingkat operasi bank tersebut. Apabila penurunan pembiayaan dan profitabilitas sudah sangat parah 
sehingga mempengaruhi profitabilitas, likuiditas dan solvabilitas suatu bank, maka kepercayaan para penitip dana terhadap bank akan menurun. Perhitungan Non Performing Financing (NPF) yang diinstruksikan oleh Bank Indonesia dengan membandingkan Total Pembiayaan Bermasalah terhadap Total Pembiayaan.

\section{Pembiayaan Mudharabah}

Dalam Pernyataan Standar Akuntansi Keungan (PSAK) 59 tentang Akuntansi Perbankan Syariah, dijelaskan karakteristik mudharabah (PSAK 59, Akuntansi Perbankan Syariah, paragraph 6 sampai dengan 11) adalah mudharabah adalah akad kerjasama usaha antara shahibul maal (pemilik dana) dan mudharib (pengelola dana) dengan nisbah bagi hasil menurut kesepakatan di muka (PSAK 59 - Akuntansi Perbankan Syariah, paragraph 6). Jika usaha mengalami kerugian maka seluruh kerugian ditanggung olehpemilik dana kecuali jika ditemukan adanya kelalaian atau kesalahan oleh pengelola dana (mudharib) seperti penyelewangan, kecurangan, dan penyalahgunaan dana.

Menurut Djuwaini (2010:224) Mudharabah berasal dari kata "dharb”, artinya memukul atau berjalan. Pengertian memukul atau berjalan ini lebih tepatnya adalah proses seseorang menggerakan kakinyadalam menjalankan usahanya. Mudharabah merupakan bahasa penduduk iraq, sedangkan menurut bahasa penduduk hijaz disebut dengan istilah qiradh.Kemudian menurut Wasilah (2013:128), mudharabah berasal dari kata adhdharby fl ardhi yaitu berpergian untuk urusan dagang. Disebut juga qiradh yang berasal dari kata alqardhu yang berarti potongan, karena pemilik memotong sebagian hartanya untuk diperdagangkan dan memperoleh sebagian keuntungan. Sedangkan menurut Abdurahim (2014:110) pembiayaan mudharabah adalah pembiayaan yang disalurkan oleh bank syariah kepada pihak lain untuk suatu usaha yang produktif.

\section{Pembiayaan Musyarakah}

Menurut PSAK 106 Paragraf 4 tentang Akuntansi Musyarakah, Musyarakah adalah akad kerjasama antara dua pihak atau lebih untuk suatu usaha tertentu, dimana masing-masing pihak memberikan kontribusi dana dengan ketentuan bahwa keuntungan dibagi berdasarkan kesepakatan sedangkan kerugian berdasarkan porsi kontribusi dana. Dana tersebut meliputi kas atau aset non kas yang diperkenankan oleh syariah. 
Menurut Abdurahim (2014:136) musyarakah berasal dari kata syirkah. Syirkah adalah pencampuran atau interaksi. Secara terminologi, syirkah adalah persekutuan usaha untuk mengambil hak atau untuk beroperasi.

Menurut Wasilah (2013:150) musyarakah merupakan akad kerja sama diantara para pemilik modal yang mencampurkan modal mereka dengan tujuan mencari keuntungan. Dalam musyarakah, para mitra sama-sama menyediakan modal untuk membiayai suatu usaha tertentu dan bekerja bersama mengelola usaha tersebut. Modal yang ada harus digunakan dalam rangka mencapai tujuan yang telah ditetapkan bersama sehingga tidak boleh digunakan untuk kepentingan pribagi atau dipinjamkan pada pihak lain tanpa seizin mitra lainnya.

Menurut Ismail (2016:146), Musyarakah merupakan akad kerja sama usaha antara dua pihak atau lebih dalam menjalankan usaha, di mana masing-masing pihak menyertakan modalnya sesuai dengan kesepakatan, dan bagi hasil atas usaha bersama diberikan sesuai dengan kontribusi dana atau sesuai kesepakatan bersama.

Menurut Bhinadi (2018:156), pembiayaan musyarakah adalah akad kerjasama yang terjadi diantara para pemilik modal (mitra musyarakah) untuk menggabungkan modal dan melakukan usaha secara bersama dalam suatu kemitraan, dengan nisbah pembagian hasil sesuai dengan kesepakatan, sedangkan kerugian ditanggung secara proporsional sesuai dengan ketentuan modal.

\section{Pembiayaan Murabahah}

Murabahah adalah akad jual beli barang dengan harga jual sebesar biaya perolehan ditambah meuntungan yang disepakati dan penjual harus mengungkapkan biaya perolehan tersebut kepada pembeli (PSAK 102 paragraf 5 tentang Akuntansi Murabahah). Definisi ini menunjukan bahwa transaksi murabahah tidak harus dalam bentuk pembayaran tangguh (kredit), melainkan dapat juga dalam bentuk tunai setelah menerima barang, ditangguhkan dengan mencicil setelah menerima barang, ataupun ditangguhkan dengan membayar sekaligus dikemudian hari (PSAK102 paragraf 8).

Menurut Ismail (2011: 109) Murabahah adalah akad jual beli atas barang tertentu, di mana penjual menyebutkan harga pembelian barang kepada pembeli kemudian menjual kepada pihak pembeli dengan mensyaratkan keuntungan yang diharapkan sesuai dengan jumlah tertentu. Dalam akad murabahah, penjual menjual 
barang dengan meminta kelebihan atas harga beli dengan harga jual. Perbedaan antara harga beli dan harga jual barang disebut dengan margin keuntungan.

Menurut Wasilah (2013:174) Murabahah adalah transaksi penjualan barang dengan menyatakan harga perolehan dan keuntungan (margin) yang disepakati oleh penjual dan pembeli. Hal yang membedakan murabahah dengan penjualan yang biasa kita kenal adalah penjual secara jelas memberi tahu kepada pembeli berapa harga pokok barang tersebut dan berapa besar keuntungan yang diinginkannya. Pembeli dan penjual dapat melakukan tawar menawar atas besaran margin keuntungan sehingga akhirnya diperoleh kesepakatan.

\section{REVIEW HASIL PENELITIAN TERDAHULU}

Beberapa penelitian tentang Pembiyaan Mudharabah, Pembiayaan Musyarakah, Pembiayaan Murabahah, Non Performing Financing (NPF) dan Return on Assets (ROA) sudah pernah dilakukan sebelumnya oleh beberapa peneliti. Penelitian yang pernah dilakukan terkait variabel diatas, antara lain:

Penelitian yang dilakukan oleh Felani dan Setiawiani (2017) dengan judul Pengaruh Pendapatan Mudharabah, Musyarakah dan Murabahah terhadap Profitabilitas pada Bank Umum Syariah Periode 2013-2015. Penelitian ini merupakan jenis penelitian kuantitatif. Populasi dalam penelitian ini adalah Bank Umum Syariah di Indonesia (BI). Sampel yang digunakan dalam penelitian ini adalah Bank Umum Syariah yang terdaftar di Bank Indonesia tahun 2013-2015. Teknik pengambilan sampel yang di pilih dengan menggunakan metode purposive sampling. Metode pengumpulan dilakukan melalui pengumpulan data sekunder. Hasil penelitian memperoleh bukti bahwa mudharabah secara parsial berpengaruh negatif terhadap ROA.Sedangakan musyarakah berpengaruh positif dan signifikan terhadap ROA. Dan untuk murabahah berpengaruh negative dan signifikan terhadap ROA pada Bank Umum Syariah.

Penelitian yang dilakukan Afif dan Mawardi (2014), dengan judul Pengaruh Pembiayaan Murabahah terhadap Laba Melalui Variabel Intervening Pembiayaan Bermasalah Bank Umum Syariah di Indonesia Periode 2009-2013. Pendekatan yang digunakan dalam penelitian ini adalah pendekatan kuantitaif . Populasi yang digunakan dalam penelitian ini adalah jumlah laporan keuangan semesteran bank umum syariah dari awal berdiri hingga tahun 2013 semester pertama. Teknik pengambilan sampel dalam penelitian ini adalah berdasarkan non probability sampling dimana tidak semua 
unit populasi memiliki kesempatan untuk dijadikan sampel penelitian. Sampel penelitian diambil secara purposive sampling. Teknik analisi data yang digunakan dalam penelitian ini adalah jalur (path analysis). Hasil dalam penelitian ini adalah pembiayaan murabahah berpengaruh positif terhadap pembiayaan bermasalah bank umum syariah. Sedangkan pembiayaan bermasalah tidak berpengaruh terhadap laba. Kemudian pembiayaan murabahah berpengaruh positif terhadap laba. Dan hasil analisi jalur ini terdapat pengaruh tidak langsung antara pembiayaan murabahah terhadap laba melalui variabel endogen intervening yaitu pembiayaan bermasalah.

Penelitian yang dilakukan oleh Romdhoni dan Yozika (2018), dengan judul Pengaruh pembiayaan mudharabah, musyarakah dan ijarah terhadap profitabilitas Bank Muamalat Indonesia. Populasi dalam peneliatian ini adalah Bank Muamalat Indonesia. Teknik pengambilan sampel dalam penelitian ini adalah purposive sampling. Penelitian ini menggunakan data sekunder. Hasil dari penelitian ini adalah pembiayaan mudharabah secara statistik tidak berpengaruh terhadap profitabilitas (ROA). Kemudian Ijarah secara statistik tidak berpengaruh terhadap profitabilitas (ROA). Sedangkan pembiayaan musyarakah secara statistik berpengaruh negatif terhadap profitabilitas (ROA). Dan pembiayaan mudharabah, musyarakah secara bersama-sama berpengaruh terhadap profitabilitas (ROA).

Penelitian yang dilakukan oleh Pratama, dkk (2017), dengan judul Pengaruh pembiayaan mudharabah, pembiayaan musyarakah dan sewa ijarah terhadap profitabilitas. Populasi dalam penelitian ini adalah Bank Muamalat Indonesia, Tbk. Sedangkann teknik pengambilan sampel yang digunakan adalah purposive sampling. Dalam penelitian ini menggunakan metode deskriptif analitis denan pendekatan kuantitatif. Hasil dalam penelitian ini adalah dari pengujian secara bersama-sama terdapat pengaruh yang signifikan antara pembiayaan mudharabah, pembiayaan musyarakah dan sewa ijarah terhadap tingkat profitabilitas. Sedangkan dari pengujian secara parsial terdapat pengaruh yang positif pembiayaan mudharabah terhadap profitabiiltas. Kemudian dari pengujian secara parsial terdapat pengaruh yang positif pembiayaan musyarakah terhadap profitabiiltas. Dan dari pengujian secara parsial terdapat pengaruh yang positif sewa ijarah terhadap profitabiiltas.

Penelitian yang dilakukan oleh Dharma dan Pristianda (2018), dengan judul Pengaruh Pembiyaan Mudharabah dan Murabahah Terhadap Profitabilitas (Return On 
Assets) Bank Pembiayaan Rakyat Syariah di Indonesia 2012-2016. Jenis penelitian ini yaitu penelitian deskriptif dengan pendekatan kuantitaif. Data yang digunakan adalah data sekunder dan teknik pengambilan sampel nya adalah purposive sampling. Hasil dalam penelitian ini adalah Mudharabah berpengaruh negatif dan tidak signifikan terhadap Profitabilitas (Return On Assets). Kemudian Murabahah berpengaruh negatif dan tidak signifikan terhadap Profitabilitas (Return On Assdets). Dan secara bersamasama pembiayaan mudharabah dan murabahah tidak signifikan terhadap Profitabilitas (Return On Assets).

Penelitian yang dilakukan oleh Chalifah dan Sodiq (2015), dengan judul Pengaruh Pendapatan Mudharabah dan Musyarakah terhadap Profitabilitas (ROA) Bank Syariah Mandiri Periode 2006-2014. Hasil dalam penelitian ini adalah pendapatan mudharabah berpengaruh positif dan signifian terhadap ROA, pendapatan musyarakah memiliki efek negatif yang signifikan terhadap ROA dan secara simultan pembiayaan mudharabah dan musyarakah berpengaruh signifikan positif terhadap ROA.

Penelitian yang dilakukan oleh Faradilla, dkk (2017) dengan judul, Pengaruh Pembiayaan Murabahah, Istishna, Ijarah, Mudharabah dan Musyarakah terhadap Profitabilitas Bank Umum Syariah di Indonesia. Adapun hasil dalam penelitian ini adalah, pembiayaan murabahah, istishna, ijarah, mudharabah dan musyarakah secara bersama-sama berpengaruh terhadap profitabilitas, pembiayaan murabahah berpengaruh positif dan signifikan terhadap profitabilitas, pembiayaan istishna tidak berpengaruh signifikan terhadap profitabilitas, pembiayaan ijarah tidak berpengaruh signifikan terhadap profitabilitas, pembiayaan mudharabah tidak berpengaruh signifikan terhadap profitabilitas, pembiayaan musyarakah berpengaruh negatif dan sigifikan terhadap profitabilitas.

Penelitian yang dilakukan oleh Nuryani dan Tandika (2019) yang berjudul, Pengaruh Pembiayaan Murabahah, Mudharabah dan Musyarakah Terhadap Tingkat Return on Asset (ROA) Pada Bank Syariah Mandiri Periode 2013-2017. Hasil dalam penelitian ini adalah pembiayaan murabahah tidak berpengaruh terhadap Return on Asset (ROA), pembiayaan mudharabah tidak berpengaruh terhadap Return on Asset 
(ROA) dan pembiayaan musyarakah tidak berpengaruh terhadap Return on Asset (ROA).

Penelitian yang dilakukam oleh Rahman dan Rochmanika (2012), dengan judul Pengaruh Pembiayaan Jual Beli, Pembiayaan Bagi Hasil, dan Rasio Non Performing Financing terhadap Profitabilitas Bank Umum Syariah di Indonesia. Adapun hasil dari penelitian ini adalah secara simultan pembiayaan jual beli, pembiayaan bagi hasil dan NPF berpengaruh signifikan terhadap profitabilitas (ROA), pembiayaan jual beli berpengaruh signifikan positif terhadap profitabilitas (ROA) dan rasio NPF berpengaruh signifikan positif terhadap profitabilitas (ROA).

Penelitian yang dilakukan oleh Septiani (2017), dengan judul Analisis Pengaruh Pembiayaan Mudharabah, Pembiayaan Musyarakah dan Pelmbiayaan Murabahah Terhadap Profitabilitas Bank Umum Syariah Yang Terdaftar di Bank Indonesia. Hasil dalam penelitian ini adalah pembiayaan mudharabah berpengaruh positif dan signifikan terhadap profitabilitas (ROA), pembiayaan musyarakah berpengaruh negatif dan signifikan terhadap profitabilitas (ROA), pembiayaan murabahah berpengaruh negatif dan signifikan terhadap profitabilitas (ROA) dan pembiayaan mudharabah, musyarakah dan murabahah secara bersama-sama berpengaruh terhadap profitabilitas (ROA)

Penelitian yang dilakukan oleh Arshed, dkk (2017), dengan judul "Financial Disintermediation and Profitability of Global Islamic Banks". Penelitian ini membadingkan dua mode dimana bank dapat melakukan pembiayaan. Model pertama adalah model keuangan (Musharaka dan Mudharaba)yang yang pada awalnya dirancang untuk bank-bank Islam, berdasarkan pembagian laba dan rugi. Yang kedua adalah model perdagangan (Ijarah dan Murabaha) yang diadopsi oleh bank-bank Islam karena kurang berisiko dan memberikan hasil yang konstan.Hasil penelitian ini menunjukan bahwa bank harus lebih focus dengan model keuangan (Musharaka dan Mudharabah). Model ini menciptakan manfaat social. Sedangkan model perdagangan (Ijarah dan Murabaha) kurang berisiko dan memberikan hasil yang konstan, tidak menguntungkan bagi pertumbuhan asset dan pertumbuhan ekuitas bank. Bank-bank syariah harus mempromosikan model keuangan karena dirancang untuk menciptakan nilai sosial, yang kedua, mereka mendorong pertumbuhan untuk perbankan syariah dan yang paling penting penggunaan instrumen ini pada akhirnya akan menghapuskan praktik riba dari sistem perbankan konvensional. Peningkatan bagian dari model 
keuangan pada akhirnya akan meningkatkan kebajikan dalam hubungan dan meningkatkan kesejahteraan.

Penelitian yangdilakukan oleh Obeidat, dkk (2012) dengan judul Evaluating the Profitability of the Islamic Banks in Jordan'. Hasil penelitian ini menemukan apa saja faktor-faktor internal dan eksternal yang membentuk profitabilitas. Faktor internal yang membentuk profitabilitas adalah total deposito, biaya deposito, total pengeluaran, pinjaman mudharabah dan deposito investasi terbatas. Secara khusus, hasil penelitian ini menunjukan dampak positif untuk biaya deposito, deposito investasi terbatas dan total pinjaman terhadap profitabilitas bank. Meskipun dampak dari total pinjaman secara statistik tidak signifikan. Di sisi lain, ada korelasi negatif antara total deposito, total pengeluaran dan pinjaman mudharabah terhadap profitabilitas.Sedangkan faktor eksternak yang membentuk profitabilitas adalah jumlah uang beredar dan pangsa pasar yang memiliki dampak positif yang signifikan terhadap profitabilitas. Dan faktor eksternal lainnya yang membentuk profitabilitas adalah bunga rediscount dan indeks harga konsumen yang memiliki dampak positif tetapi tidak signifikan terhadap profitabilitas.

Penelitian yang dilakuka oleh Amira, dkk (2014) yang berjudul, Islamic Credit Risk Management in Murabahah Financing-The Study of Islamic Banking in Malaysia. Hasil dalam penelitian ini menemukan bahwa ada beberapa penentu risiko dalam pembiayaan murabahah di Malaysia yang harus ditangani dan di kurangi oleh industry perbankan. Risiko tersebut termasuk seperti risiko penetapan harga, risiko komoditas, risiko pasar dan risiko kredit. Adapun cara untuk mengurangi risiko kredit adalah dengan menggunakan jaminan yang diberikan oleh rekanan tingkat. Ditemukan bahwa, risiko kredit bisa diminimalkan dengan meningkatkan daftar referensi pada kinerja masa lalu klien dan karakter mereka serta memiliki database yang komprehensif. Selain itu, system peringkat kredit harus divalidasi pda interval yang tekah ditentukan serta setiap kali ada parameter baru yang dimodifikasi karena kondisi pasar.

\section{Pengaruh Pembiayaan Mudharabah terhadap ROA}

Pembiayaan yang diberikan oleh bank kepada nasabah akan mendapatkan balas jasa berupa bagi hasil, margin keuntungan dan pendapatan sewa, tergantung pada akad pembiayaan yang diperjanjikan antara bank syariah dan mitra usaha (nasabah). Pembiayaan akan berpengaruh pada peningkatan profitabilitas bank. Hal ini dapat 
tercermin pada perolehan laba. Dengan adanya peningkatan laba usaha bank akan menyebabkan kenaikan tingkat profitabilitas bank, menurut Ismail (2016:87). Dalam penelitian ini perhitungan profitabilitas menggunakan sebuah alat pengukuran yang disebut ROA (Return on Asset).

Menurut Chalifah (2015) pendapatan mudharabah berpengaruh positif dan signifikan terhadap ROA. Kemudian menurut Felani (2017) mudharabah secara parsial berpengaruh negatif terhadap ROA. Sedangkan menurut Romdhoni (2018) pembiayaan mudharabah secara statistik tidak berpengaruh terhadap profitabilitas (ROA).

$\mathrm{H}_{1}$ : Pembiayaan Mudharabah berpengaruh terhadap Profitabilitas (ROA).

\section{Pengaruh Pembiayaan Musyarakah terhadap ROA}

Pembiayaan yang diberikan oleh bank kepada nasabah akan mendapatkan balas jasa berupa bagi hasil, margin keuntungan dan pendapatan sewa, tergantung pada akad pembiayaan yang diperjanjikan antara bank syariah dan mitra usaha (nasabah). Pembiayaan akan berpengaruh pada peningkatan profitabilitas bank. Hal ini dapat tercermin pada perolehan laba. Dengan adanya peningkatan laba usaha bank akan menyebabkan kenaikan tingkat profitabilitas bank, menurut Ismail (2016:87). Dalam penelitian ini perhitungan profitabilitas menggunakan sebuah alat pengukuran yang disebut ROA (Return on Asset).

Menurut Felani (2017) musyarakah mempunyai pengaruh yang positif dan signifikan terhadap ROA. Artinya semakin tinggi pendapatan musyarakah maka akan meningkatkan profitabilitas ROA. Sedangkan menurut Chalifah (2015) pendapatan musyarakah memiliki efek negatif yang signifikan terhadap ROA. Namun menurut Nuryani (2019) pembiayaan musyarakah tidak berpengaruh terhadap Return on Asset (ROA).

$\mathrm{H}_{2}$ : Pembiayaan Musyarakah berpengaruh terhadap Profitabilitas (ROA).

\section{Pengaruh Pembiayaan Murabahah terhadap ROA}

Pembiayaan yang diberikan oleh bank kepada nasabah akan mendapatkan balas jasa berupa bagi hasil, margin keuntungan dan pendapatan sewa, tergantung pada akad pembiayaan yang diperjanjikan antara bank syariah dan mitra usaha (nasabah). Pembiayaan akan berpengaruh pada peningkatan profitabilitas bank. Hal ini dapat tercermin pada perolehan laba. Dengan adanya peningkatan laba usaha bank akan menyebabkan kenaikan tingkat profitabilitas bank, menurut Ismail (2016:87). Dalam 
penelitian ini perhitungan profitabilitas menggunakan sebuah alat pengukuran yang disebut ROA (Return on Asset).

Meurut Faradilla (2017) pembiayaan murabahah berpengaruh positif dan signifikan terhadap profitabilitas. Kemudian menurut Felani (2017) murabahah mempunyai pengaruh yang negatif dan signifikan terhadap ROA. Artinya semakin tinggi tingkat murabahah maka semakin rendah ROA bank umum syariah. Hal ini berarti bahwa murabahah tidak dapat meningkatkan laba di lembaga keuangan syariah. Sedangkan meurut Nuryani (2019) pembiayaan murabahah tidak berpengaruh terhadap Return on Asset (ROA)

$\mathrm{H}_{3}$ : Pembiayaan Murabahah berpengaruh terhadap Profitabilitas (ROA).

\section{Pengaruh Pembiayaan Mudharabah terhadap NPF}

Risiko pembiayaan muncul jika bank tidak bisa memperoleh kembali cicilan pokok dan atau bunga dari pinjaman yang diberikan atau investasi yang sedang dilakukannya. Penyebab utama terjadinya risiko pembiayaan adalah terlalu mudahnya bank memberikan pinjaman atau melakukan investasi karena terlalu dituntut untuk memanfaatkan kelebihan likuiditas, sehingga penilaian kredit kurang cermat dalam mengantisipasi berbagai kemungkinan risiko usaha yang dibiayai, menurut Muhammad (2011:358). Hal ini menunjukan bahwa semakin tinggi bank syariah menyalurkan pembiayaan, maka akan mengakibatkan risiko pembiayaan yang dinilai melalui Non Performing Financing (NPF), menurut Muhammad (2004:143) dalam Afif (2014).

$\mathrm{H}_{4}$ : Pembiayaan Mudharabah berpengaruh terhadap Non Performing Financing (NPF).

\section{Pengaruh Pembiayaan Musyarakah terhadap NPF}

Risiko pembiayaan muncul jika bank tidak bisa memperoleh kembali cicilan pokok dan atau bunga dari pinjaman yang diberikan atau investasi yang sedang dilakukannya. Penyebab utama terjadinya risiko pembiayaan adalah terlalu mudahnya bank memberikan pinjaman atau melakukan investasi karena terlalu dituntut untuk memanfaatkan kelebihan likuiditas, sehingga penilaian kredit kurang cermat dalam mengantisipasi berbagai kemungkinan risiko usaha yang dibiayai, menurut Muhammad (2011:358). Hal ini menunjukan bahwa semakin tinggi bank syariah menyalurkan pembiayaan, maka akan mengakibatkan risiko pembiayaan yang dinilai melalui Non Performing Financing (NPF), menurut Muhammad (2004:143) dalam Afif (2014). 
$\mathrm{H}_{5}$ : Pembiayaan Musyarakah berpengaruh terhadap Non Performing Financing (NPF).

\section{Pengaruh Pembiayaan Murabahah terhadap NPF}

Risiko pembiayaan muncul jika bank tidak bisa memperoleh kembali cicilan pokok dan atau bunga dari pinjaman yang diberikan atau investasi yang sedang dilakukannya. Penyebab utama terjadinya risiko pembiayaan adalah terlalu mudahnya bank memberikan pinjaman atau melakukan investasi karena terlalu dituntut untuk memanfaatkan kelebihan likuiditas, sehingga penilaian kredit kurang cermat dalam mengantisipasi berbagai kemungkinan risiko usaha yang dibiayai, menurut Muhammad (2011:358). Hal ini menunjukan bahwa semakin tinggi bank syariah menyalurkan pembiayaan, maka akan mengakibatkan risiko pembiayaan yang dinilai melalui Non Performing Financing (NPF), menurut Muhammad (2004:143) dalam Afif (2014). Pembiayaan murabahah berpengaruh positif terhadap pembiayaan bermasalah bank umum syariah, menurut Afif (2014).

$\mathrm{H}_{6}$ : Pembiayaan Murabahah berpengaruh terhadap Non Performing Financing (NPF).

\section{Pengaruh NPF terhadap ROA}

Menurut Ikatan Bankir Indonesia (2015:309), Non Performing Financing (NPF) adalah kredit bermasalah yang terdiri dari kredit yang berklasifikasi Kredit Kurang Lancar, Kredit Diragukan dan Kredit Macet. Termin Non Performing Loan (NPL) digunakan bagi bank umum, sedangkan Non Performing Financing (NPF) digunakan untuk bank syariah.

Menurut Rahman (2012) rasio NPF berpengaruh signifikan positif terhadap profitabilitas (ROA). Sedangkan menurut Prasetyo (2010) rasio NPL memiliki pengaruh yang negatif terhadap profitabilitas. Namun menurut Fitriyani (2019) Non Performing Financing (NPF) tidak berpengaruh terhadap Profitabilitas. Jadi hipotesis pengaruh NPF tehadap ROA adalah sebagai berikut:

$\mathrm{H}_{7}$ : Non Performing Financing (NPF) berpengaruh terhadap Profitabilitas (ROA).

\section{Pengaruh Pembiayaan Mudharabah terhadap ROA melalui NPF}

Menurut Septiani (2017) pembiayaan mudharabah berpengaruh positif dan signifikan terhadap profitabilitas (ROA). Faradilla (2017) Pembiayaan mudharabah tidak berpengaruh signifikan terhadap profitabilitas. Menurut Felani (2017) 
mudharabah secara parsial berpengaruh negatif terhadap ROA. Hal ini diakibatkan karena pada pembiayaan mudharabah akan meningkatkan biaya yang dikeluarkan oleh lembaga keuangan sehingga laba yang di dapat kemungkinan tidak sesuai dengan yang di harapkan.

$\mathrm{H}_{8}$ : Pembiayaan Mudharabah berpengaruh terhadap Profitabilitas (ROA) melalui Non Performing Financing (NPF).

\section{Pengaruh Pembiayaan Musyarakah terhadap ROA melalui NPF}

Menurut Pratama (2017) secara parsial terdapat pengaruh yang positif pembiayaan musyarakah terhadap profitabiiltas. Sedangkan menurut Faradilla (2017) pembiayaan musyarakah berpengaruh negatif dan sigifikan terhadap profitabilitas,

$\mathrm{H}_{9}$ : Pembiayaan Musyarakah berpengaruh terhadap Profitabilitas (ROA) melalui Non Performing Financing (NPF).

\section{Pengaruh Pembiayaan Murabahah terhadap ROA melalui NPF}

Menurut Dharma (2018) murabahah berpengaruh negatif dan tidak signifikan terhadap Profitabilitas (Return On Assdets). Sedangkan menurut Afif (2014) terdapat pengaruh tidak langsung antara pembiayaan murabahah terhadap laba melalui variabel intervening yaitu pembiayaan bermasalah. Hasil analisis jalur untuk pengaruh tidak langsung lebih kecil dibandingkan dengan pengaruh langsungnya.

$\mathrm{H}_{10}$ : Pembiayaan Murabahah berpengaruh terhadap Profitabilitas (ROA) melalui Non Performing Financing (NPF).

\section{METODE PENELITIAN}

Strategi penelitian yang digunakan dalam penelitian ini adalah penelitian kausalitas. Menurut Sanusi (2016:14), penelitian kausalitas adalah desain penelitian yang disusun untuk meneliti kemungkinan adanya hubungan sebab-akibat antar variabel.

Dalam penelitian ini pendekatan yang digunakan adalah metode penelitan kuantitatif. Menurut Sugiyono (2013:13) metode penelitian kuantitatif dapat diartikan sebagai metode penelitian yang berlandaskan pada filsafat positivisme, digunakan untuk meneliti pada populasi atau sampel tertentu, teknik pengambilan sampel umumnya 
dilakukan secara random, pengumpulan data menggunakan instrumen penelitian, analisis data bersifat kuantitatif/statistik dengan tujuan untuk menguji hipotesis yang telah ditetapkan.

\subsection{ANALISIS DATA}

\section{Uji Asumsi Klasik}

\section{Uji Normalitas}

Uji Normalitas ini dilakukan untuk mengetahui apakah data-data yang diperoleh sebagai variabel-variabel terpilih tersebut berdistribusi normal atau tidak. Pada penelitian ini uji normalitas digunakan dengan metode pendekatan Jarque-Bera. Normalitas suatu data juga dapat ditunjukkan dengan nilai probabilitas Jarque-Bera > 0,05. Namun, jika probabilitas Jarque-Bera $<0,05$; maka data tersebut terbukti tidak normal. Dari hasil yang didapatkan bahwa nilai probabilitas sebesar 0,576801. Dengan demikian dapat dikatakan bahwa data normal karena probabilitas jarquebera $(0,576801)$ $>0,05$.

\section{Uji Autokorelasi}

Autokorelasi berarti adanya hubungan antara residual satu observasi dengan residual observasi lainnya. Dalam pengujian autokorelasi ini, peneliti menggunakan uji Durbin-Watson (DW test). Untuk mengidentifikasi adanya autokorelasi dilakukan dengan melihat nilai Durbin Watson (DW stat) dan membandingkannya di dalam tabel Durbin-Watson. hasil Durbin-Watson statistik (DW stat) yaitu sebesar 1,342890. Selanjutnya dibandingkan nilai DW stat dengan DW tabel yang terdiri dari dua nilai yaitu batas bawah $(\mathrm{dL})$ dan batas atas $(\mathrm{dU})$. Dengan $\mathrm{k}=3$ karena jumlah variabel bebas yang digunakan sebanyak 3 dan $\mathrm{n}=66$, maka didapatkan pada tabel Durbin Watson ( $\alpha$ $=5 \%$ ) batas $\mathrm{dL}$ yaitu 1,5079 dan dU yaitu 1,6974. Maka dapat dinyatakan bahwa hasil dari uji statistik Durbin-Watson berada pada daerah dU $\leq \mathrm{d} \leq 4$-dU atau 1,6974 $\leq$ $1.890324 \leq 2,3026$ sehingga dapat diputuskan bahwa Ho diterima karena tidak terdapat autokorelasi.

\section{Uji Multikolinieritas}

Uji Multikolinearitas bertujuan untuk menguji apakah model regresi ditemukan adanya korelasi antar variabel independen. Model regresi yang baik seharusnya tidak terjadi korelasi antara variabel independen. Multikolinieritas dapat dilihat dari nilai 
Variance Inflation Factor (VIF), jika VIF < 10 maka tidak terjadi multikolinearitas, sedangkan dika VIF $\geq 10$ maka terjadi multikolinearitas. Dari hasil menunjukan bahwa tidak nilai VIF pembiayaan mudharabah sebesar $3.505307<10$, maka tidak terjadi multikolinearitas. Sedangkan untuk pembiayaan musyarakah sebesar $3.255058<10$, maka tidak terjadi multikolinearitas. Kemudian nilai pembiayaan murabahah sebesar $1.841331<10$, maka tidak terjadi multikolinearitas. Dan untuk nilai NPF sebesar $1.090273<10$, maka tidak terjadi multikolinearitas. Dengan demikian tidak terjadi adanya multikolinearitas antar variabel pada penelitian ini.

\section{Uji Heteroskedastisitas}

Pengujian heteroskedastisitas bertujuan untuk menguji apakah dalam model regresi terjadi ketidaksamaan varian dari residual satu pengamatan ke pengamatan lain. Untuk menguji heteroskedastisitas, peneliti menggunakan uji Breusch-Pagan. Kriteria uji heteroskedastisitas adalah jika nilai probabilitas Chi-Square $<0,05$ maka data terdapat heteroskedastisitas, dan sebaliknya data dikatakan tidak terdapat heteroskedastisitas saat nilai probabilitas Chi-Square > 0,05. Nilai probabilitas ChiSquare sebesar 0.1851. Hasil ini menunjukkan bahwa nilai probabilitas Chi-Square lebih besar dari 0,05, maka dapat disimpulkan tidak terdapat heteroskedastisitas pada data.

\section{Pengujian Model}

Uji model data panel dalam menentukan model yang tepat pada setiap persamaan. Dalam menentukan pemilihan model yang tepat.

Tabel 3.Pengujian Model Regresi Data Panel

\begin{tabular}{|c|c|c|c|}
\hline \multicolumn{4}{|l|}{ Model 1 (NPF) } \\
\hline Metode & Pengujian & Hasil & Kesimpulan \\
\hline Uji Chow & $\begin{array}{l}\text { Comman Effect Model } \\
\text { vs Fixed Effect Model }\end{array}$ & $\begin{array}{l}\text { Fixed Effect } \\
\text { Model }\end{array}$ & \multirow{2}{*}{$\begin{array}{l}\text { Fixed Effect } \\
\text { Model (FEM) }\end{array}$} \\
\hline Uji Hausman & $\begin{array}{l}\text { Fixed Effect Model vs } \\
\text { Random Effect Model }\end{array}$ & $\begin{array}{l}\text { Fixed Effect } \\
\text { Model }\end{array}$ & \\
\hline \multicolumn{4}{|l|}{ Model 2(ROA) } \\
\hline Metode & Pengujian & Hasil & Kesimpulan \\
\hline Uji Chow & $\begin{array}{l}\text { Comman Effect Model } \\
\text { vs Fixed Effect Model }\end{array}$ & $\begin{array}{l}\text { Fixed Effect } \\
\text { Model }\end{array}$ & \multirow{2}{*}{$\begin{array}{l}\text { Fixed Effect } \\
\text { Model (FEM) }\end{array}$} \\
\hline Uji Hausman & $\begin{array}{l}\text { Fixed Effect Model vs } \\
\text { Random Effect Model }\end{array}$ & $\begin{array}{l}\text { Fixed Effect } \\
\text { Model }\end{array}$ & \\
\hline
\end{tabular}

Dari hasil pengujian model regresi data panel di atas, didapatkan hasil yang merekomendasikan penggunaan model Fixed Effect Model yang akan dianalisis lebih lanjut dalam penelitian ini. 


\section{Analisis Fixed Effect Model (NPF)}

Pengujian Fixed Effect Model (FEM) dilakukan menggunakan metode Panel Least Square, dengan NPF sebagai dependen variabel dan menemukan hasil bahwa $\mathrm{R}^{2}$ sebesar 0,9999 atau sebesar $99.99 \%$.

\section{Tabel 4. Hasil Analisis Fixed Effect Model (NPF)}

\begin{tabular}{|c|c|c|c|c|}
\hline \multicolumn{5}{|c|}{$\begin{array}{l}\text { Dependent Variable: NPF } \\
\text { Method: Panel Least Squares } \\
\text { Date: } 10 / 10 / 19 \text { Time: } 09: 25 \\
\text { Sample: } 20132018 \\
\text { Periods included: } 6 \\
\text { Cross-sections included: } 11 \\
\text { Total panel (unbslanced) observations: } 60\end{array}$} \\
\hline Variable & Coefficient & Std. Error & t-Statistic & Prob. \\
\hline Pembiayagn Mudharabah & -0.000159 & 0.000215 & -0.740174 & 0.0004 \\
\hline Pembigyasn Musyarakah & 0.000167 & 0.000283 & 0.592081 & 0.0000 \\
\hline Pembigygan Murabahah & -0.000108 & 0.000514 & -0.209866 & 0.0300 \\
\hline ROA & -0.019365 & 0.003878 & -4.993260 & 0.0000 \\
\hline $\mathrm{c}$ & 0.004259 & 0.015755 & 0.270321 & 0.7882 \\
\hline$X_{1} \cdot z_{-}$ROA & $-4.14 \mathrm{E}-12$ & 1.16E-12 & -3.565962 & 0.0009 \\
\hline$X 2 * Z_{-} R O A$ & $6.47 \mathrm{E}-13$ & $1.40 \mathrm{E}-13$ & 4.618872 & 0.0000 \\
\hline$X 3^{*} Z_{-} R O A$ & $3.55 \mathrm{E}-13$ & $6.45 \mathrm{E}-14$ & 5.502952 & 0.0000 \\
\hline \multicolumn{5}{|c|}{ Effects Specification } \\
\hline \multicolumn{5}{|c|}{ Cross-section foxed (dummy variables) } \\
\hline R-squared & 0.999999 & \multicolumn{2}{|c|}{ Mean dependent var } & 0.135950 \\
\hline Adjusted R-squared & 0.999998 & \multicolumn{2}{|c|}{ S.D. dependent var } & 0.618245 \\
\hline S.E. of regression & 0.000834 & \multicolumn{2}{|c|}{ Aksike info criterion } & -11.09770 \\
\hline Sum squared resid & $2.92 \mathrm{E}-05$ & \multicolumn{2}{|c|}{ Sohwgrz criterion } & -10.46940 \\
\hline Log likelihood & 350.9310 & \multicolumn{2}{|c|}{ Hannan-Quinn criter. } & -10.85194 \\
\hline F-statistic & 1907841. & \multicolumn{2}{|c|}{ Durbin-Wstson stat } & 2.471151 \\
\hline Prob(F-statistic) & 0.000000 & & & \\
\hline
\end{tabular}

\section{Analisis Fixed Effect Model (ROA)}

Pengujian Fixed Effect Model (FEM) dilakukan menggunakan metode Panel Least Square, dengan ROA sebagai dependen variabel dan menemukan hasil bahwa $\mathrm{R}^{2}$ sebesar 0,9997 atau sebesar $99.97 \%$.

\begin{tabular}{|c|c|c|c|c|}
\hline \multicolumn{5}{|c|}{$\begin{array}{l}\text { Dependent Variable: ROA } \\
\text { Method: Psnel Least Squares } \\
\text { Dste: } 10 / 10 / 19 \text { Time: } 09: 18 \\
\text { Sample: } 20132018 \\
\text { Periods included: } 6 \\
\text { Cross-sections included: } 11 \\
\text { Total panel (unbslanced) observations: } 60\end{array}$} \\
\hline Variable & Coefficient & Std. Error & t-Statistic & Prob. \\
\hline Pembiaysen Mudharabah & -0.000116 & 0.000180 & -0.641911 & 0.0014 \\
\hline Pembiayasn Musyarakah & -0.000806 & 0.000212 & -3.803652 & 0.0005 \\
\hline Pembisyaan Murabahah & -0.000524 & 0.000389 & -1.346332 & 0.0104 \\
\hline NPF & $-7.18 \mathrm{E}-05$ & 0.000182 & -0.394276 & 0.0954 \\
\hline & 0.040732 & 0.013446 & 3.029407 & 0.0042 \\
\hline$X 1^{-} Y_{\text {_NNPF }}$ & 0.003603 & 0.001814 & 1.986508 & 0.0135 \\
\hline$\times 2^{*} Y_{-}^{-} \mathrm{NPF}$ & 0.014261 & 0.006018 & 2.369939 & 0.0225 \\
\hline$\times 3^{*} Y_{-}^{-} N P F$ & 0.015223 & 0.006088 & 2.500627 & 0.0100 \\
\hline \multicolumn{5}{|c|}{ Effects Specification } \\
\hline \multicolumn{5}{|c|}{ Cross-section foxed (dummy variables) } \\
\hline R-squared & 0.999731 & \multirow{7}{*}{\multicolumn{2}{|c|}{$\begin{array}{l}\text { Mean dependent var } \\
\text { S.D. dependent var } \\
\text { Akgike info oriterion } \\
\text { Schwarz criterion } \\
\text { Hannan-Quinn criter. } \\
\text { Durbin-Watson stat }\end{array}$}} & -0.000465 \\
\hline Adjusted R-squared & 0.999623 & & & 0.036765 \\
\hline S.E. of regression & 0.000714 & & & -11.40723 \\
\hline Sum squared resid & 2.14E-05 & & & -10.77893 \\
\hline Log likelihood & 360.2170 & & & -11.16147 \\
\hline F-statistic & 9191.646 & & & 2.421328 \\
\hline Prob(F-statistic) & 0.000000 & & & \\
\hline
\end{tabular}

\section{Analisis Regresi Linier Berganda}

Untuk menganalisis pengaaruh pembiayaan mudharabah, pembiayaan musyarakah, pembiayaan murabahah terhadap ROA melalui non performing financing sebagai variabel intervening pada Bank Umum Syariah pada periode 2013-2018, maka 
penulisan menggunakan teknik analisis regresi data panel. Berdasarkan hasil, diperoleh bentuk persamaan sebagai berikut:

\section{$\mathrm{NPF}=0.004259-0.000159$ MUDHARABAH +0.000167 MUSYARAKAH - 0.0000108 MURABAHAH}

ROA $=0.040732-0.000116$ MUDHARABAH - 0.000806 MUSYARAKAH - 0.000524

Hasil pengujian hipotesis adalah sebagai berikut:

1. Variabel pembiayaan mudharabah memiliki nilai signifikansi sebesar $0.0014 \leq$ 0.05 dengan nilai $\beta_{1}$ sebesar -0.000116 (Negatif). Dengan demikian, $\mathrm{Ha}_{1}$ yang menyatakan bahwa "Pembiayaan mudharabah berpengaruh negatif terhadap ROA pada Bank Umum Syariah yang terdaftar di OJK periode 2013-2018” diterima.

2. Vaiabel pembiayaan musyarakah memiliki nilai signifikansi sebesar $0.0005 \leq 0.05$ dengan nilai $\beta_{2}$ sebesar -0.000806 (Negatif). Dengan demikian $\mathrm{Ha}_{2}$ yang menyatakan bahwa "Pembiayaan musyarakah berpengaruh negatif terhadap ROA pada Bank Umum Syariah yang terdaftar di OJK periode 2013-2018” diterima.

3. Vaiabel pembiayaan murabahah memiliki nilai signifikansi sebesar $0.0104 \leq 0.05$ dengan nilai $\beta_{3}$ sebesar -0.000524 (Negatif). Dengan demikian $\mathrm{Ha}_{3}$ yang menyatakan bahwa "Pembiayaan murabahah berpengaruh negatif terhadap ROA pada Bank Umum Syariah yang terdaftar di OJK periode 2013-2018" diterima.

4. Vaiabel pembiayaan mudharabah memiliki nilai signifikansi sebesar $0.0004 \leq 0.05$ dengan nilai $\beta_{4}$ sebesar -0.000159 (Negatif). Dengan demikian $\mathrm{Ha}_{4}$ yang menyatakan bahwa "Pembiayaan mudharabah berpengaruh negatif terhadap NPF pada Bank Umum Syariah yang terdaftar di OJK periode 2013-2018” diterima.

5. Vaiabel pembiayaan musyarakah memiliki nilai signifikansi sebesar $0.0000 \leq 0.05$ dengan nilai $\beta_{5}$ sebesar 0.000167 (Positif). Dengan demikian $\mathrm{Ha}_{5}$ yang menyatakan bahwa "Pembiayaan musyarakah berpengaruh positif terhadap NPF pada Bank Umum Syariah yang terdaftar di OJK periode 2013-2018” diterima.

6. Vaiabel pembiayaan murabahah memiliki nilai signifikansi sebesar $0.0300 \leq 0.05$ dengan nilai $\beta_{6}$ sebesar -0.000108 (Negatif). Dengan demikian $\mathrm{Ha}_{6}$ yang menyatakan bahwa "Pembiayaan murabahah berpengaruh negatif terhadap NPF pada Bank Umum Syariah yang terdaftar di OJK periode 2013-2018” diterima.

7. Vaiabel non performing financing memiliki nilai signifikansi sebesar $0.0954>0.05$ dengan nilai $\beta_{6}$ sebesar $-7.18 \mathrm{E}-05$ (Negatif). Dengan demikian $\mathrm{Ha}_{7}$ yang 
menyatakan bahwa "Non performing financing tidak berpengaruh terhadap ROA pada Bank Umum Syariah yang terdaftar di OJK periode 2013-2018” ditolak.

8. Variabel pembiayaan mudharabah memiliki nilai signifikansi sebesar $0.0009 \leq$ 0.05 dengan nilai $\beta_{1}$ sebesar $-4.14 \mathrm{E}-12$ (Negatif). Dengan demikian, $\mathrm{Ha}_{8}$ yang menyatakan bahwa "Pembiayaan mudharabah berpengaruh negatif terhadap ROA melalui NPF sebagai variabel intervening pada Bank Umum Syariah yang terdaftar di OJK periode 2013-2018” diterima.

9. Variabel pembiayaan musyarakah memiliki nilai signifikansi sebesar $0.0000 \leq 0.05$ dengan nilai $\beta_{1}$ sebesar 6.47E-13 (Positif). Dengan demikian, $\mathrm{Ha}_{9}$ yang menyatakan bahwa "Pembiayaan musyarakah berpengaruh positif terhadap ROA melalui NPF sebagai variabel intervening pada Bank Umum Syariah yang terdaftar di OJK periode 2013-2018" diterima.

10. Variabel pembiayaan murabahah memiliki nilai signifikansi sebesar $0.0000 \leq 0.05$ dengan nilai $\beta_{1}$ sebesar 3.55E-13 (Positif). Dengan demikian, $\mathrm{Ha}_{10}$ yang menyatakan bahwa "Pembiayaan murabahah berpengaruh positif terhadap ROA melalui NPF sebagai variabel intervening pada Bank Umum Syariah yang terdaftar di OJK periode 2013-2018” diterima.

\subsection{PEMBAHASAN}

\section{Pengaruh Pembiayaan Mudharabah terhadap ROA}

Hasil penelitian menyimpulkan bahwa pembiayaan mudharabah berpengaruh negatif dan signifikan terhadap ROA. Artinya penyaluran pemberian dana mudharabah yang tinggi akan menurunkan keuntungan bagi perbankan.Hal ini diakibatkan karena pada pembiayaan mudharabah akan meningkatkan biaya yang dikeluarkan oleh bank sehingga laba yang didapat kemungkinan tidak sesuai dengan yang diharapkan. Pendapatan bagi hasil bank umum syariah yang diperoleh dari penyaluran pembiayaan mudharabah (bagi hasil) kemungkinan masih belum optimal diperoleh sehingga belum mampu mengimbangi biaya-biaya yang dikeluarkan.

Hal ini dapat disebabkan karena kurang nya bank dalam menjalankan prinsip kehati-hatian (prudential banking).Bank dalam melakukan penilaian terhadap pemohon pembiayaan haruslah memperhatikan kondisi calon nasabah nya. Hal ini dapat diukur dengan 5C \& 1S yaitu, Character, Capacity, Capital, Collateral, Condition dan Syariah. Character dapat dilihat dari karakter atau kepribadian calon nasabah. Capacity 
yaitu kemampuan calon nasabah dalam melakukan pembayaran. Collateral yaitu jaminan yang dimiliki oleh calon nasabah. Capital yaitu kemampuan modal calon nasabah. Condition yaitu bank harus dapat melihat kondisi ekonomi yang terjadi di masyarakat. Sedangkan Syariah adalah untuk melihat apakah bidang usaha calon nasabah tidak bertentangan dengan prinsip syariah.

Hasil penelitian ini sejalan dengan penelitian yang dilakukan oleh dan Permata (2014) dan Felani (2017) yang menyatakan bahwa mudharabah secara parsial berpengaruh negatif terhadap ROA.

\section{Pengaruh Pembiayaan Musyarakah terhadap ROA}

Hasil penelitian menunjukan bahwa pembiayaan musyarakah berpengaruh negatif terhadap ROA. Artinya penyaluran pemberian dana musyarakah yang tinggi akan menurunkan keuntungan bagi perbankan.Hal ini diakibatkan karena pada pembiayaan musyarakah akan meningkatkan biaya yang dikeluarkan oleh bank sehingga laba yang didapat kemungkinan tidak sesuai dengan yang diharapkan. Pendapatan bagi hasil bank umum syariah yang diperoleh dari penyaluran pembiayaan musyarakah (bagi hasil) kemungkinan masih belum optimal diperoleh sehingga belum mampu mengimbangi biaya-biaya yang dikeluarkan. Hal ini dapat disebabkan karena kurang nya bank dalam menjalankan prinsip kehati-hatian (prudential banking).Bank dalam melakukan penilaian terhadap pemohon pembiayaan haruslah memperhatikan kondisi calon nasabah nya. Hal ini dapat diukur dengan 5C \& $1 \mathrm{~S}$ yaitu, Character, Capacity, Capital, Collateral, Condition dan Syariah. Character dapat dilihat dari karakter atau kepribadian calon nasabah.Capacity yaitu kemampuan calon nasabah dalam melakukan pembayaran. Collateral yaitu jaminan yang dimiliki oleh calon nasabah. Capital yaitu kemampuan modal calon nasabah. Condition yaitu bank harus dapat melihat kondisi ekonomi yang terjadi di masyarakat. Sedangkan Syariah adalah untuk melihat apakah bidang usaha calon nasabah tidak bertentangan dengan prinsip syariah.

Hal ini sejalan dengan penelitian yang dilakukan oleh Chalifah (2015) yang menyatakan bahwa pendapatan musyarakah memiliki efek negatif yang signifikan terhadap ROA 


\section{Pengaruh Pembiayaan Murabahah terhadap ROA}

Hasil penelitian menunjukan bahwa pembiayaan murabahah berpengaruh negatif terhadap ROA. Artinya penyaluran pemberian dana murabahah yang tinggi akan menurunkan keuntungan bagi perbankan.Hal ini diakibatkan karena pada pembiayaan murabahah akan meningkatkan biaya yang dikeluarkan oleh bank sehingga laba yang didapat kemungkinan tidak sesuai dengan yang diharapkan. Pendapatan bagi hasil bank umum syariah yang diperoleh dari penyaluran pembiayaan murabahah (bagi hasil) kemungkinan masih belum optimal diperoleh sehingga belum mampumengimbangi biaya-biaya yang dikeluarkan. Hal ini dapat disebabkan karena kurang nya bank dalam menjalankan prinsip kehati-hatian (prudential banking).Bank dalam melakukan penilaian terhadap pemohon pembiayaan haruslah memperhatikan kondisi calon nasabah nya. Hal ini dapat diukur dengan 5C \& $1 \mathrm{~S}$ yaitu, Character, Capacity, Capital, Collateral, Condition dan Syariah. Character dapat dilihat dari karakter atau kepribadian calon nasabah.Capacity yaitu kemampuan calon nasabah dalam melakukan pembayaran. Collateral yaitu jaminan yang dimiliki oleh calon nasabah. Capital yaitu kemampuan modal calon nasabah. Condition yaitu bank harus dapat melihat kondisi ekonomi yang terjadi di masyarakat. Sedangkan Syariah adalah untuk melihat apakah bidang usaha calon nasabah tidak bertentangan dengan prinsip syariah.

Hal ini sejalan dengan penelitian yang dilakukan oleh Anjani (2016) dan Felani (2017) yang menyatakan pembiayaan murabahah mempunyai pengaruh yang negatif dan signifikan terhadap ROA

\section{Pengaruh Pembiayaan Mudharabah terhadap NPF}

Hasil penelitian ini menunjukan bahwa pembiayaan mudharabah berpengaruh negatif terhadap NPF. Hal ini menujukan bahwa semakin tinggi nya tingkat pembiayaan mudharabah yang diberikan oleh bank kepada nasabah nya maka akan berdampak pada penurunan risiko kredit macet nya atau NPF. Hal ini dapat disebabkan karena Capacity atau kemampuan nasabah dalam melakukan pembayaran lancar atau baik. Sehingga dapat meminimalisir risiko kredit macet 


\section{Pengaruh Pembiayaan Musyarakah terhadap NPF}

Hasil penelitian ini menunjukan bahwa pembiayaan musyarakah berpengaruh positif terhadap NPF. Artinya semakin tinggi nya tingkat pembiayaan musyarakah yang diberikan oleh bank kepada nasabah nya maka akan semakin tinggi pula tingkat risiko kredit macet atau NPF pada bank tersebut. Karena dengan adanya pembiayaan yang diberikan tidak terlepas dari risiko kredit macet.

\section{Pengaruh Pembiayaan Murabahah terhadap NPF}

Hasil penelitian ini menunjukan pembiayaan murabahah berpengaruh negatif terhadap NPF. Artinya bahwa semakin tinggi nya tingkat pembiayaan murabahah yang diberikan oleh bank kepada nasabah nya maka akan berdampak pada penurunan risiko kredit macet nya atau NPF. Hal ini dapat disebabkan karena Capacity atau kemampuan nasabah dalam melakukan pembayaran lancar atau baik. Sehingga dapat meminimalisir risiko kredit macet.

\section{Pengaruh NPF terhadap ROA}

Hasil penelitian menunjukan bahwa non performing financing tidak berpengaruh terhadap ROA. Hal ini berarti bahwa kondisi NPF yang lebih besar dalam satu periode tidak secara langsung. Hal ini dikarenakan pengaruh yang signifikan dari NPF terhadap ROA akan berkaitan dengan tingkat kemacetan pembiayaan yang diberikan oleh bank. Dalam hal ini karena pembiayaan merupakan sumber utama pendapatan bank. Dan juga disisi lain NPF yang tinggi akan dapat mengganggu perputaran modal kerja dari bank. Maka jika bank memiliki jumlah pembiayaan macet yang tinggi, maka bank akan berusaha mengevaluasi kinerja dengan menghentikan sementara pembiayaan, agar NPF dapat berkurang.

Hal ini sejalan dengan penelitian yang dilakukan oleh Wibowo (2013), Slamet (2014) dan Fitriyani (2019) yang menyatakan bahwa NPF secara parsial tidak berpengaruh terhadap ROA.

\section{Pengaruh Pembiayaan Mudharabah terhadap ROA melalui NPF}

Hasil penelitian ini menunjukan bahwa pembiayaan mudharabah berpengaruh negatif terhadap ROA melalui NPF sebagai variabel intervening. Dari hasil analisis jalur ini menunjukan adanya pengaruh tidak langsung antara pembiayaan mudharabah terhadap ROA melalui NPF. Namun jika dibandingkan dengan hasil pengaruh 
langsung, hasil dari pengaruh tidak langsung jauh lebih kecil dibandingkan dengan pengaruh langsung. Oleh karena itu, analisis variabel pembiayaan mudharabah terhadap ROA lebih baik dianalisis melalui pengaruh langsung.

\section{Pengaruh Pembiayaan Musyarakah terhadap ROA melalui NPF}

Hasil penelitian ini pembiayaan musyarakah berpengaruh positif terhadap ROA melalui NPF sebagai variabel intervening. Dari hasil analisis jalur ini menunjukan adanya pengaruh tidak langsung antara pembiayaan musyarakah terhadap ROA melalui NPF. Namun jika dibandingkan dengan hasil pengaruh langsung, hasil dari pengaruh tidak langsung jauh lebih kecil dibandingkan dengan pengaruh langsung. Oleh karena itu, analisis variabel pembiayaan mudharabah terhadap ROA lebih baik dianalisis melalui pengaruh langsung.

\section{Pengaruh Pembiayaan Murabahah terhadap ROA melalui NPF}

Hasil penelitian ini pembiayaan murabahah berpengaruh positif terhadap ROA melalui NPF sebagai variabel intervening. Dari hasil analisis jalur ini menunjukan adanya pengaruh tidak langsung antara pembiayaan terhadap ROA melalui NPF. Namun jika dibandingkan dengan hasil pengaruh langsung, hasil dari pengaruh tidak langsung jauh lebih kecil dibandingkan dengan pengaruh langsung. Oleh karena itu, analisis variabel pembiayaan mudharabah terhadap ROA lebih baik dianalisis melalui pengaruh langsung.

\section{SIMPULAN DAN SARAN}

\subsection{Simpulan}

1. Pembiayaan mudharabah berpengaruh negatif dan signifikan terhadap ROA. Artinya penyaluran pemberian dana mudharabah yang tinggi akan menurunkan keuntungan bagi perbankan.

2. Pembiayaan musyarakah berpengaruh negatif terhadap ROA. Artinya penyaluran pemberian dana musyarakah yang tinggi akan menurunkan keuntungan bagi perbankan.

3. Pembiayaan murabahah berpengaruh negatif terhadap ROA. Artinya penyaluran pemberian dana murabahah yang tinggi akan menurunkan keuntungan bagi perbankan. 
4. Pembiayaan mudharabah berpengaruh negatif terhadap NPF. Hal ini menujukan bahwa semakin tinggi nya tingkat pembiayaan mudharabah yang diberikan oleh bank kepada nasabah nya maka akan berdampak pada penurunan risiko kredit macet nya atau NPF.

5. Pembiayaan musyarakah berpengaruh positif terhadap NPF. Artinya semakin tinggi nya tingkat pembiayaan musyarakah yang diberikan oleh bank kepada nasabah nya maka akan semakin tinggi pula tingkat risiko kredit macet atau NPF pada bank tersebut.

6. Pembiayaan murabahah berpengaruh negatif terhadap NPF. Artinya bahwa semakin tinggi nya tingkat pembiayaan murabahah yang diberikan oleh bank kepada nasabah nya maka akan berdampak pada penurunan risiko kredit macet nya atau NPF.

7. Non performing financing tidak berpengaruh terhadap ROA. Hal ini berarti bahwa kondisi NPF yang lebih besar dalam satu periode tidak secara langsung. Hal ini dikarenakan pengaruh yang signifikan dari NPF terhadap ROA akan berkaitan dengan tingkat kemacetan pembiayaan yang diberikan oleh bank. Dalam hal ini karena pembiayaan merupakan sumber utama pendapatan bank. Dan juga disisi lain NPF yang tinggi akan dapat mengganggu perputaran modal kerja dari bank.

8. Pembiayaan mudharabah berpengaruh negatif terhadap ROA melalui NPF sebagai variabel intervening. Dari hasil analisis jalur ini menunjukan adanya pengaruh tidak langsung antara pembiayaan mudharabah terhadap ROA melalui NPF. Namun jika dibandingkan dengan hasil pengaruh langsung, hasil dari pengaruh tidak langsung jauh lebih kecil dibandingkan dengan pengaruh langsung.

9. Pembiayaan musyarakah berpengaruh positif terhadap ROA melalui NPF sebagai variabel intervening. Dari hasil analisis jalur ini menunjukan adanya pengaruh tidak langsung antara pembiayaan musyarakah terhadap ROA melalui NPF. Namun jika dibandingkan dengan hasil pengaruh langsung, hasil dari pengaruh tidak langsung jauh lebih kecil dibandingkan dengan pengaruh langsung.

10. Pembiayaan murabahah berpengaruh positif terhadap ROA melalui NPF sebagai variabel intervening. Dari hasil analisis jalur ini menunjukan adanya pengaruh tidak langsung antara pembiayaan terhadap ROA melalui NPF. Namun jika 
dibandingkan dengan hasil pengaruh langsung, hasil dari pengaruh tidak langsung jauh lebih kecil dibandingkan dengan pengaruh langsung.

\subsection{Saran}

Peneliti merekomendasikan saran berdasarkan kesimpulan sebagai berikut:

1. Bagi perbankan

Bagi pihak perbankan peneliti menyarankan untuk lebih memperhatikan tingkat kehari-hatian dalam memberikan pembiayaan kepada calon nasabah. Agar dapat mengurangi tingkat kredit macet.

2. Bagi regulator (Pemerintah)

Sebagai pembuat kebijakan, diharapkan pemerintah memberikan dukungan penuh untuk pengembangan pembiayaan syariah. Sehingga dapat meningkatkan profitabilitas dan efisiensi untuk terus maju dan berkembang bersama pemerintah.

3. Bagi peneliti selanjutnya

Diharapkan dapat meneliti variabel lainnya yang berkaitan dengan pembiayaan mudharabah, musyarakah, murabahah, NPF dan ROA. Disamping itu perlu untuk memperpanjang periode penelitian guna lebih baik akan meningkatkan keakuratan data penelitian sehingga diperoleh estimasi yang lebih representatif.

\section{DAFTAR PUSTAKA}

Abdullah, Faisal. 2010. Manajemen Perbankan. Cetakan Ketiga. UUM Press. Malang. Abdurahim, Ahim, Aji Erlangga dan Rizal Yaya. 2014. Akuntansi Perbankan. Syariah Edisi 2 (Teori dan Praktik Kontemporer). Jakarta: Salemba Empat.

Aditya Muhammad Rizal dan Mahendra Adhi Nugroho. 2016. Pengaruh Pembiyaan Mudharabah dan Pembiayaan Musyarakah terhadap Tingkat Profitabilitas Bank Umum Syariah 2010-2014. Jurnal Profita Edisi 4 Tahun 2016.

Adyani, Lyla Rahma Adyani dan Djoko Sampurno. 2012. Analisis Faktor-Faktor yang Mempengaruhi Profitabilitas (ROA) pada Bank Umum Syariah Periode 20052010. Cendekia Akuntansi Vol.1 No.3 - September 2012. ISSN 2338-3593.

Afif, Zaim Nur dan Mawardi, Imron. 2014. Pengaruh Pembiayaan Murabahah Terhadap Laba Melalui Variabel Intervening Pembiayaan Bermasalah Bank Umum Syariah di Indonesia Periode 2009-2013. JESTT Vol.1 No.8 Agustus 2014. 
Agustiningrum Riski .2012. Analisis Pengaruh CAR, NPL dan LDR Terhadap Profitabilitas Pada Perusahaan Perbankan. E-Jurnal Management

Agza Yunita dan Darwanto. 2017. Pengaruh Pembiayaan Murabahah, Musyarakah dan Biaya Transaksi Terhadap Profitabilitas Bank Pembiayaan Rakyat Syariah. Jurnal Kajian Ekonomi dan Bisnis Volume 10 No 1 2017. P-ISSN : 1979-0724. E-ISSN : $2502-3993$

Amira, Siti Nor, dkk. 2014. Islamic Credit Risk Management in Murabahah FinancingThe Study of Islamic Banking in Malaysia. Australian Journal of Basic and Applied Sciences. ISSN : 1991-8178

Anjani Rivalah dan Maulidiyah Indira Hasmarani. 2016. Pengaruh Pembiayaan Mudharabah, Musyarakah dan Murabahah terhadap Profitabilitas BPRS di Indonesia Periode 2012-2015. ISSN 2460-0784. Menakar Peran Profesi sebagai Engine of Reform dalam Pembangunan Global Berkelanjutan.

Arikunto. 2010. Prosedur Penelitian: Suatu Pendekatan Praktek. Jakarta:Rineka Cipta. Arshed Noman, Shakeel Riaz, Tahseen Mohsan Khan dan Osama Aziz (2017), Financial Disintermediation and Profitability of Global Islamic Banks.EJIFEuropean Journal of Islamic Finance.No. 7. ISSN 2421-2172

Baltagi, Badi H. 2005 Econometirc Analysis of Panel Data $3^{\text {th }}$ ed John Wiley \& Scons Ltd. Chichester.

Bambang Juanda dan Junaid. 2012. Ekonometrika Deret Waktu: Teori dan Aplikasi. IPB Press

Bhinadi Ardito. 2018. Muamalah Syar'iyyah Hidup Barokah.Yogyakarta: Deepublish.

Chalifah, Ela dan Sodiq, Amirus. 2015. Pengaruh Pendapatan Mudharabah dan Musyarakah terhadap Profitabilitas (ROA) Bank Syariah Mandiri Periode 20062014. Jurnal Ekonomik Syariah Equilibrium, Vol 3 No 1 Juni 2015

Dharma ,Yulius dan Pristianda, Ade. 2018. Pengaruh Pembiyaan Mudharabah dan Murabahah Terhadap Profitabilitas (Return On Assets) Bank Pembiayaan Rakyat Syariah di Indonesia 2012-2016. Jurnal Ekonomika Indonesia Volume VII Nomor 02 Desember 2018. P-ISSN : 2338-4123 E ISSN:2614-7270

Djuwaini, Dimyauddin. 2010, Pengantar Fiqh Muamalah, Yogyakarta: Pustaka Kencana. 
Faradilla, Cut, Arfan, Muhamad dan Shabri, M. 2017. Pengaruh Pembiayaan Murabahah, Istishna, Ijarah, Mudharabah dan Musyarakah terhadap Profitabilitas Bank Umum Syariah di Indonesia. Jurnal Magister Akuntansi Pascasarjana Universitas Syiah Kuala.

Felani, Herman dan Setiawiani, Intan Gina. 2017. Pengaruh Pendapatan Mudharabah, Musyarakah dan Murabahah Tehadap Profitabilitas Pada Bank Uum Syariah Periode 2013-2015. ISSN 2460-0784. Peran Profesi Akuntansi Dalam Penanggulangan Korupsi.

Fitriyani, Ana, Masitoh, Endang dan Suhendro. 2019. Pengaruh Pembiayaan Murabahah, Mudharabah dan Non Performin Financing (NPF) Terhadap Profitabilitas Bank Umum Syariah Yang Terdaftar di Bank Indonesia Tahun 2014-2017. Jurnal Widya Ganeswara Volume 2 No 12019 : ISSN 0853-0521

Ghozali, Imam. 2011. Aplikasi Analisis Multivariate Dengan Program IBM SPSS 19. Edisi Kelima. Semarang: Univeristas Diponegoro.

Ghozali, Imam. 2012. Analisis Multivariate dengan program SPSS. Semarang: Badan Penerbit Universitas Diponegoro.

Hadiyati Puji. (2013). Pengaruh Non Performing Financing Pembiayaan Mudharabah dan Musyarakah pada Bank Muamalat Indonesia. E-Jurnal Manajemen dan Bisnis, Vol. 1 No.1 Oktober 2013.

Hanafi, M. Mamduhdan Abdul Halim. 2016. Analisis Laporan Keuangan. Yogyakarta: UPP STIM YKPN.

Harun Usman. 2016. Pengaruh Rasio-Ratio Keuangan CAR, LDR, NIM, BOPO, NPL

Terhadap ROA. Jurnal Riset Bisnis dan Manajemen Vol 4, No 1 , 2016: 67-82

Hery. 2016. Analisa Laporan Keuangan Integrated and Comprehensive Edition. Penerbit. Jakarta : PT. Grasindo

Hery. 2015. Analisis Kinerja Manajemen: The Best Financial Analysis Menilai Kinerja Manajemen Berdasarkan Rasio Keuangan, Jakarta: PT Grasindo

Ikatan Bankir Indonesia. 2015. Bisnis Kredit Perbankan. Jakarta: PT. Gramedia Pustaka Utama.

Ismail. 2016. Perbankan Syariah. Jakarta: Kencana

Kadir. 2010. Statistika, untuk Penelitian Ilmu-IlmuSosial. Jakarta: Rosemata Sampurna. Kasmir. 2012. Manajemen Perbankan. Jakarta: PT Raja Grafindo Persada. 
Machmud, Amir dan Rukmana, 2010, Bank Syariah, Teori, kebijakan, dan Studi Empiris di Indonesia. Jakarta: Erlangga.

Mahmoeddin As. 2010. Melacak Kredit Bermasalah. Cetakan Pertama. Jakarta: Pustaka Sinar Harapan.

Muhammad. 2011. Manajemen Bank Syariah. Yogyakarta: UPP Sekolah Tinggi Manajemen YKPN

Nachrowidan Usman.2006. Pendekatan Populer dan Praktis Ekonometrika untuk Analisis Ekonomi dan Keuangan. Jakarta: Lembaga Penerbit Fakultas Ekonomi Universitas Indonesia

Neolaka Amos. 2014. Metode Penelitian dan Statistik.Bandung: Remaja Rosdakarya

Nuryani, Kristin dan Tandika, Didik. 2019. Pengaruh Pembiayaan Murabahah, Mudharabah dan Musyarakah Terhadap Tingkat Return on Asset (ROA) Pada Bank Syariah Mandiri Periode 2013-2017. Prosiding Manajemen ISSN: 24606545

Obeidat Bader Yousef, Salaheddin Y. El-Rimawi, Ra'ed (Moh'dTaisir) Masa'deh. Mahmoud Mohammad Maqablehdan Idris Mohammed Al-Jarrah. 2012. Evaluating the Profitability of the Islamic Banks in Jordan.European Journal of Economics, Finance and Administative Sciences. ISSN 1450-2275

Prasetyo Wawan, 2015. Analisis Faktor-Faktor yang Mempengaruhi Analisis Perbankan. JESP-Vol. 7 No. 1 Maret 2015. ISSN 2086-1575.

Pratama Ditha Nada, Lia Dwi Martika dan Teti Rahmawati. 2017. Pengaruh Pembiayaan Mudharabah, Pembiayaan Musyarakah dan Sewa Ijarah Terhadap Profitabilitas. JRKA Volume 3 Issue 1, Februari 2017 : 53-68

Puji Hadiyati. (2013). Pengaruh Non Performing Financing Pembiayaan Mudharabah dan Musyarakah pada Bank Muamalat Indonesia. E-Jurnal Manajemen dan Bisnis, Vol. 1 No.1 Oktober 2013.

Rahman, Aulia Fuad dan Rochmanika, Ridha. 2012. Pengaruh Pembiayaan Jual Beli, Pembiayaan Bagi Hasil, dan Rasio Non Performing Financing terhadap Profitabilitas Bank Umum Syariah di Indonesia

Riyadi Slamet dan Agung Yulianto. 2014. Pengaruh Pembiayaan Bagi Hasil, Pembiayaan Jual Beli, Financing to Deposit Ratio (FDR) dan Non Performing 
Financing (NPF) Terhadap Profitabilitas Bank Umum Syariah di Indonesia. Accounting Analysis Journal ISSN 2252-6765

Romdhoni, A Haris dan Yozika, Ferlangga Al. 2018. Pengaruh Pembiayaan Mudharabah, Musyarakah dan Ijarah Terhadap Profitabilitas Bank Muamalat Indonesia. Jurnal Ilmiah Ekonomi Islam , 4 (03), 2018, 177-18.

Sanusi Anwar. 2016. Metode Penelitian Bisnis. Jakarta: SalembaEmpat.

Santoso, Singgih. 2012. Statistik Parametik. Jakarta: PT Gramedia Pustaka Umum.

Septiani Atika. 2017. Analisis Pengaruh Pembiayaan Mudharabah, Pembiayaan

Musyarakah dan Pelmbiayaan Murabahah Terhadap Profitabilitas Bank Umum

Syariah Yang Terdaftar di Bank Indonesia. IBS-2017

Shomad, Abd dan Usanti Triadini P. 2016. Hukum Perbankan. Jakarta: Kencana

Sudarsono, Heri. 2012. Bank dan Lembaga Keuangan Syariah. EdisiKeempat. Yogyakarta: Ekonisia.

Sugiyono. 2010.Statistika untuk Penelitian. Bandung: Alfabeta

Sugiyono. 2012. Metode Penelitian Kuantitatif dan R\&B. Bandung: Alfabeta.

Sugiyono. 2013. Metode Penelitian Bisnis. Bandung: Alfabeta

Tandelilin Eduardus. 2010. Portofolio dan Investasi (Teori dan Aplikasi). Yogyakarta:

PT Kanisius

Taswan. 2010. Manajemen Perbankan, Konsep, Teknik, dan Aplikasi. Edisi Kedua. Yogyakarta : UPP STIM YKPN.

Triyuwono, Iwan. 2015. Akuntansi Syariah: Perspektif, Metodelogi, dan Teori. Jakarta: PT. Raja Grafindo Persada.

Warnida Titi Dewi. 2013. Dynamic Model of Islamic Bank Profitability. Journal of Islamic Banking \& Finance, Global Perspective on Islamic Finance

Wasilah dan Nurhayati Siti. 2013. Akuntansi Syariah di Indonesia, Jakarta: Salemba Empat.

Wibowo Arief dan Sunarto. 2016. Pengaruh Pembiayaan Mudharabah dan Musyarakah terhadap Profitabilitas Perbankan Syariah (Studi Kasus pada Bank Pembiayaan Rakyat Syariah Daerah Istimewa Yogyakarta yang terdaftar di Bank Indonesia Periode 2012-2014). ISSN 2460-0784. Syariah Paper Acounting FEB UMS. Seminar Nasional dan The 3rd Call for Syariah Paper. 
Wibowo Edhi Satriyo dan Muhammad Syaichu. 2013. Analisis Pengaruh Suku Bunga, Insflasi, CAR, BOPO, NPF Terhadap Profitabilitas Bank Syariah. Diponegoro Journal of Management Volume 2, Nomor 2, Tahun 2013 Halaman 1-10. ISSN (Online): 2337:3792

Winarno, Wing Wahyu. 2013. Analisis Ekonometrika dan Statistika dengan Eviews. Yogyakarta: UUP STIM YKPN.

Yulianah dan Euis Komariah. 2017. Risiko Pembiayaan Murabahah, Mudharabah dan Musyarakah BUS Terhadap Profitabilitas ROA Periode 2011-2015. Profita Volume 10 No 1 April 2017

Yusmad Muammar Arafat, 2018. Aspek Hukum Perbankan Syariah Dari Teori Ke Praktik. Yogyakarta: Deepublish. 